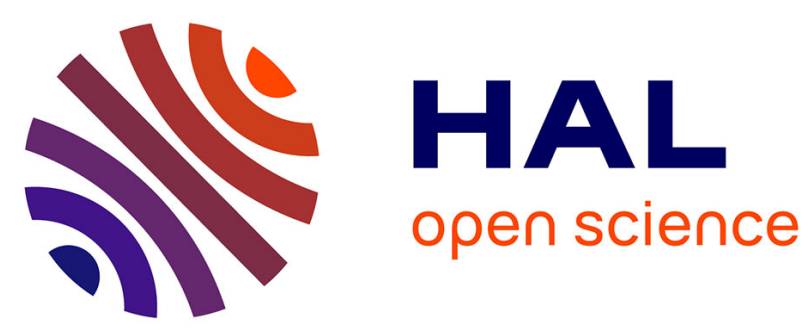

\title{
Enantioselective Syntheses of Furan Atropisomers by an Oxidative Central-to-Axial Chirality Conversion Strategy
}

Vivek S Raut, Marion Jean, Nicolas Vanthuyne, Christian Roussel, Thierry

Constantieux, Cyril Bressy, Xavier Bugaut, Damien Bonne, Jean Rodriguez

\section{To cite this version:}

Vivek S Raut, Marion Jean, Nicolas Vanthuyne, Christian Roussel, Thierry Constantieux, et al.. Enantioselective Syntheses of Furan Atropisomers by an Oxidative Central-to-Axial Chirality Conversion Strategy. Journal of the American Chemical Society, 2017, 139 (6), pp.2140-2143. 10.1021/jacs.6b11079 . hal-01533761

\section{HAL Id: hal-01533761 https://hal.science/hal-01533761}

Submitted on 6 Jun 2017

HAL is a multi-disciplinary open access archive for the deposit and dissemination of scientific research documents, whether they are published or not. The documents may come from teaching and research institutions in France or abroad, or from public or private research centers.
L'archive ouverte pluridisciplinaire HAL, est destinée au dépôt et à la diffusion de documents scientifiques de niveau recherche, publiés ou non, émanant des établissements d'enseignement et de recherche français ou étrangers, des laboratoires publics ou privés. 


\section{Enantioselective Syntheses of Furan Atropisomers by an Oxidative Central-to-Axial Chirality Conversion Strategy}

Vivek S. Raut, Marion Jean, Nicolas Vanthuyne, Christian Roussel, Thierry Constantieux, Cyril Bressy, Xavier Bugaut, Damien Bonne, ${ }^{*} \odot$ and Jean Rodriguez*

Aix Marseille Univ, CNRS, Centrale Marseille, iSm2, Marseille, France

ABSTRACT: For the first time, enantiomerically enriched atropoisomeric furans have been accessed using a centralto-axial chirality conversion strategy. Hence, oxidation of the enantioenriched dihydrofuran precursors gave rise to axially chiral furans with high enantiopurities accounting from excellent conversion percentages (cp) in most cases.

Tonracemic axially chiral molecules are of utmost interest 1 for a wide cross section of chemists due to their numerous applications as chiral ligands, ${ }^{1}$ organocatalysts, ${ }^{2}$ and materials ${ }^{3}$ but also for their biological relevance. ${ }^{4}$ Among them, biaryl atropisomers are the most common ones and many synthetic approaches are available. ${ }^{5}$ In sharp contrast, the much more challenging enantioselective construction of atropisomeric heteroaryl structures still constitutes a daunting challenge of modern organic synthesis. ${ }^{6}$ The presence of a heteroatom not only can bring new synthetic and biologic perspectives but also can be used for the control of the reactivity based on the possible establishment of additional hydrogen-bonding interactions. Therefore, the design of new dedicated enantioselective synthetic strategies to access new families of atropisomeric heteroaryls is highly desirable. ${ }^{7}$ However, the situation becomes drastically more difficult when the targeted heteroatropisomeric species display a five-membered heterocycle because of the increased distance between aryl substituents resulting in generally much lower barriers to rotation hampering the conformational stability (Scheme 1a). ${ }^{8}$ To the best of our knowledge, the only example concerning the enantioselective construction of five-membered heteroatropisomers has been reported by Itami and Yamaguchi in 2012. They described a Pd-catalyzed enantioselective $\mathrm{C}-\mathrm{H}$ coupling methodology between the two preformed aromatic partners affording a thiophene atropisomer isolated in only $27 \%$ yield and $72 \%$ ee. ${ }^{9,10}$ A more appealing but challenging approach would rely on the construction of the heteroaromatic ring with the concomitant creation of the stereogenic axis. We decided to tackle this synthetic defiance considering the easy formation of a furan ring 4 by oxidation of a chiral dihydrofuran precursor 3 in line with the central-to-axial chirality conversion ${ }^{11,12}$ strategy developed in our group. ${ }^{13}$ This will open a new synthetic way to access hitherto unknown atropisomeric furans $\mathbf{4}$ in optically active form (Scheme $1 \mathrm{~b}$ ). The overall sequence is initiated by an enantioselective organocatalyzed 1,4-addition of diverse pronucleophiles such as 1,3-dicarbonyls ${ }^{14} 1$ or $\beta$-naphthols ${ }^{15} 5$ to (Z)-(2-halo-2-nitroethenyl)benzenes ${ }^{16} 2$ triggering an intra-
Scheme 1. Synthetic Plan to Furan Atropisomers

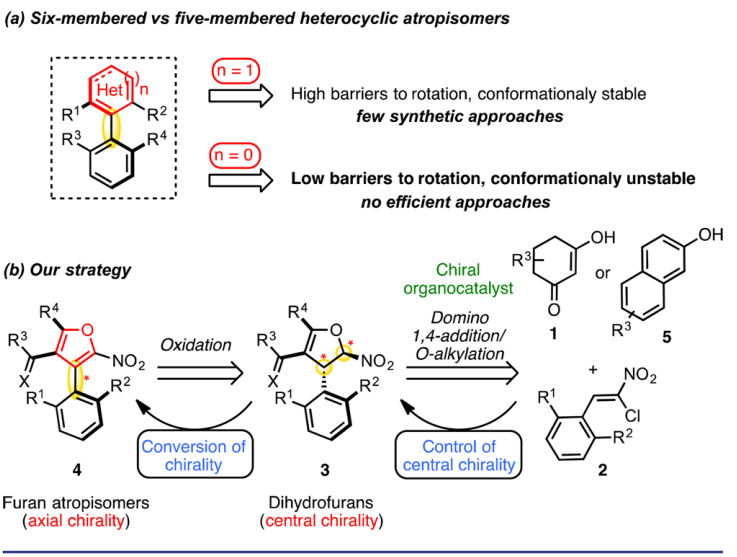

molecular diastereoselective $\mathrm{O}$-alkylation leading to transdihydrofurans precursors of the final furans upon oxidation.

To reach this goal, two main difficulties needed to be addressed: first, the efficient enantioselective synthesis of dihydrofurans bearing bulky 2,6-disubstituted phenyl moieties, in order to reach high enough barriers to rotation. Second, mild and selective oxidative conditions in order to preserve enantiomeric purity during the conversion of chirality step. Our initial investigations started by the optimization of the dihydrofuran synthesis by screening of various organocatalysts with dimedone (1a) and bulky $\beta$-substituted nitroolefin $\mathbf{2} \mathbf{a}$ as model substrates (Scheme 2). Among different bifunctional organocatalysts, the ones incorporating a squaramide moiety were the most efficient and the use of catalyst 6 afforded the desired trans-dihydrofuran $3 a$ in $92 \%$ yield and $95 \%$ ee. ${ }^{17}$ Oxidative conditions to form chiral furan $4 \mathbf{a}$ were studied, and we found that the use of hypervalent iodine reagents under basic conditions ${ }^{18}$ allowed to reach best efficiencies in the central-to-axial chirality conversion process. (Diacetoxyiodo)benzene $\left[\mathrm{PhI}(\mathrm{OAc})_{2}\right]$ was the most efficient and we noticed an important effect of the base (see Supporting Information). Hence, compared to classical organic bases $\left(\mathrm{Et}_{3} \mathrm{~N}, \mathrm{DMAP}\right)$, inorganic base cesium carbonate gave the best results both in terms of yield and conversion percentage (cp) up to $94 \%$ for 4a, which displays a very good stability with a barrier to rotation 
Scheme 2. Optimization of the Reaction Conditions

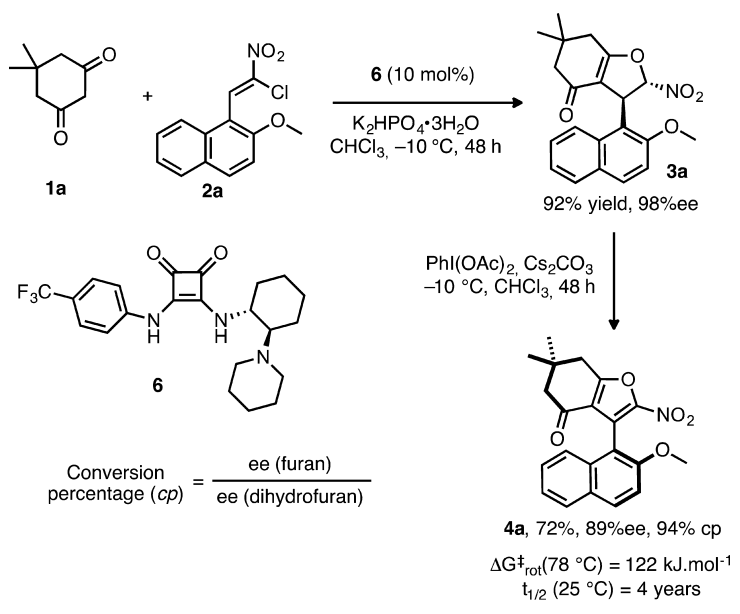

of $122 \mathrm{~kJ} \mathrm{~mol}^{-1}$. The use of other oxidizing agents gave inferior results. For example, manganese dioxide afforded $\mathbf{4 a}$ in only $32 \%$ yield with $15 \% \mathrm{cp}$.

We next assessed the scope of this transformation by varying the nature of the 1,3-diketone partner (Scheme 3). Starting

Scheme 3. Reaction Scope ${ }^{a}$

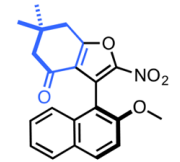

4 a, $65 \%, 89 \%$ ee, $91 \%$ cp $\Delta \mathrm{G}_{\mathrm{rot}}^{\ddagger}\left(78^{\circ} \mathrm{C}\right)=122 \mathrm{~kJ}^{\mathrm{mol}}{ }^{-1}$

$\mathrm{t}_{1 / 2}\left(25^{\circ} \mathrm{C}\right)=4$ years

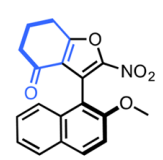

4b, $47 \%, 86 \%$ ee, $90 \%$ cp

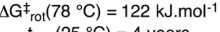
$\mathrm{t}_{1 / 2}\left(25^{\circ} \mathrm{C}\right)=4$ years

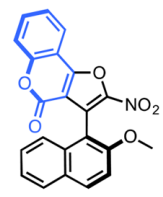

4d, $82 \%, 79 \%$ ee, $84 \%$ cp $\Delta \mathrm{G}_{\mathrm{rot}}^{\ddagger}\left(78^{\circ} \mathrm{C}\right)=124 \mathrm{~kJ} \cdot \mathrm{mol}^{-1}$

$\mathrm{t}_{1 / 2}\left(25^{\circ} \mathrm{C}\right)=9$ years

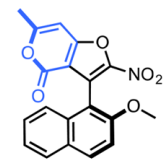

4c, $74 \%, 87 \%$ ee, $92 \%$ cp $\Delta \mathrm{G}_{\mathrm{rot}}^{\mp}\left(78^{\circ} \mathrm{C}\right)=125 \mathrm{~kJ}^{\mathrm{mol}}{ }^{-1}$ $\mathrm{t}_{1 / 2}\left(25^{\circ} \mathrm{C}\right)=10$ years
${ }^{a}$ Yields are for two steps.

with cyclohexan-1,3-dione led to the formation of the corresponding furan $\mathbf{4 b}$ with similar efficiency even if the yield during the oxidation step slightly decreased. Cyclic ketoesters or ketoamides could also be employed as starting materials leading to the desired furans $4 \mathbf{c}-\mathbf{e}$ in good yields and good enantiopurity, with barriers to rotation from 122 to $135 \mathrm{~kJ}$ $\mathrm{mol}^{-1}$. Concerning the stereochemical assignment, $4 \mathrm{~d}$ as well as its dihydrofuran precursor $\mathbf{3 d}$ were crystallized and absolute configurations of these molecules were unambiguously identified by X-ray diffraction as $(2 S, 3 S)-\mathbf{3 d}$ and $(\mathrm{aS})-\mathbf{4 d} .^{19}$ Scheme 4 shows our current understanding of the reaction pathway and its stereochemical outcome. From $(S, S)-3 d$, proton abstraction by $\mathrm{Cs}_{2} \mathrm{CO}_{3}$ would give the chiral nitronate anion 7 , in which the fast rotation of the methoxynaphthyl group around the $C s p 2-C s p 3$ bond shields significantly the $\beta$ -
Scheme 4. $\mathrm{PhI}(\mathrm{OAc})_{2}$ Oxidation Mechanism

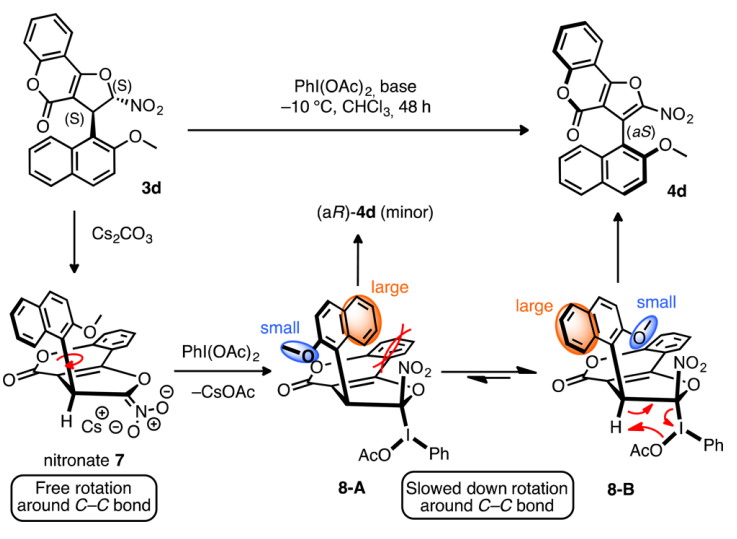

face. Therefore, we can assume that the approach of $\mathrm{PhI}(\mathrm{OAc})_{2}$ occurs preferentially from the $\alpha$-face delivering two rotamers 8A and 8-B with a transient restricted rotation of the methoxynaphthyl group because of the resulting cis relationship with the nitro group. Finally, the minimum steric congestion developed in 8-B accounts for an efficient central-to-axial chirality conversion resulting in the highly selective formation of optically active furan (aS)-4d. This constitutes the first efficient enantioselective approach to furan atropisomers. However, the use of a naphthyl substituent at the 3 position of the furan ring is mandatory to reach high enough barriers to rotation, and only the methoxy function provides isolable compounds after oxidation. ${ }^{20}$

To overcome this limitation, and expand the range of applications of our strategy, we focused on related 3-phenylnaphtho[2,1-b]furan atropisomers 10a potentially accessible from $\beta$-naphthol (5a) as pro-nucleophile and o-bromo-3-phenyl nitroolefin 2b (Scheme 5). Gratifyingly, using the same

Scheme 5. Reaction Conditions Optimization

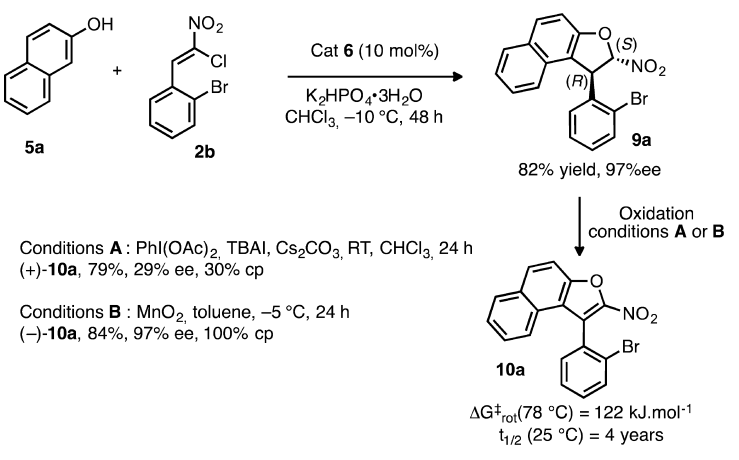

catalytic system as before, a smooth $\mathrm{O}$-cycloalkylation occurred at $-10{ }^{\circ} \mathrm{C}$ and dihydrofuran $9 \mathrm{a}$ was isolated in $82 \%$ yield and an excellent $97 \%$ ee. However, the oxidation step using hypervalent iodine (condition A) was less efficient in this series. The corresponding naphthofuran 10a was produced in a satisfying $79 \%$ yield but only $29 \%$ ee $(30 \% \mathrm{cp})$. However, the barrier to rotation of $10 \mathrm{a}\left(122 \mathrm{~kJ} \mathrm{~mol}^{-1}\right)$ was in agreement with our expectations and this molecule nicely complements with the previous family of furan atropisomers 4 . The screening of other oxidizing agents was carried out and to our delight, the 
use of manganese dioxide $\left(\mathrm{MnO}_{2}\right.$, conditions $\left.\mathrm{B}\right)$ in toluene at $-5{ }^{\circ} \mathrm{C}$ promoted the oxidation of $9 \mathrm{a}$ to 3-phenyl-naphthofuran atropisomer 10a with total chirality conversion (84\% yield, $97 \%$ ee, $100 \% c p$ ). Interestingly, these two oxidizing systems $\left[\mathrm{PhI}(\mathrm{OAc})_{2}\right.$ under basic conditions and $\mathrm{MnO}_{2}$ ] afforded opposite enantiomers (+)-10a and (-)-10a, respectively pointing out two different mechanisms with opposite stereochemical outcomes. ${ }^{12 \mathrm{~d}}$

With the optimized conditions in hand, we next examined the scope of the nitroalkene partner (Scheme 6). Other

\section{Scheme 6. Reaction Scope ${ }^{a}$}

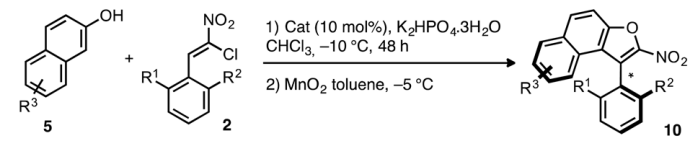

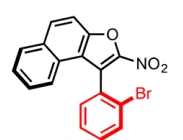

10a, 63\%, $97 \%$ $\Delta \mathrm{G}^{ \pm} \mathrm{rot}_{\mathrm{rot}}\left(78^{\circ} \mathrm{C}\right)=122 \mathrm{~kJ} . \mathrm{mo}$ $\mathrm{t}_{1 / 2}\left(25^{\circ} \mathrm{C}\right)=4$ years

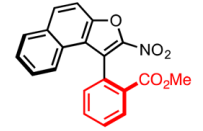

10d, $61 \%, 95 \%$ ee, $99 \%$ cp $\mathrm{G}_{\mathrm{rot}}\left(78^{\circ} \mathrm{C}\right)=110.6 \mathrm{~kJ} \cdot \mathrm{m}$

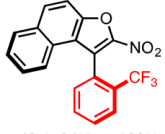

$10 \mathrm{~g}, 42 \%, 94 \% \mathrm{ee}, 100 \% \mathrm{cp}$ $\mathrm{G}^{\mp}$ rot $\left(132{ }^{\circ} \mathrm{C}\right)=142 \mathrm{~kJ}$.mo

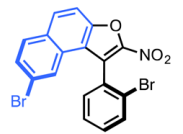
$10 \mathrm{j}, 80 \%, 95 \% \mathrm{ee}, 100 \% \mathrm{cp}$
$\Delta \mathrm{G}^{\mp}{ }_{\mathrm{rot}}\left(78{ }^{\circ} \mathrm{C}\right)=124 \mathrm{~kJ} . \mathrm{mol}^{-1}$ $t_{1 / 2}\left(25^{\circ} \mathrm{C}\right)=9$ years

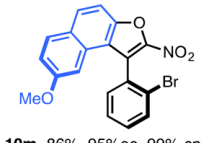

$10 \mathrm{~m}, 86 \%, 95 \% \mathrm{ee}, 99 \% \mathrm{cp}$ $\Delta \mathrm{G}^{\ddagger} \mathrm{rot}\left(78^{\circ} \mathrm{C}\right)=125 \mathrm{~kJ}^{\mathrm{mol}}$ $\mathrm{t}_{1 / 2}\left(25^{\circ} \mathrm{C}\right)=10$ years

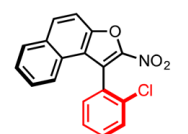

10b, $75 \%, 93 \%$ ee, $96 \%$ cp $\begin{aligned} \Delta \mathrm{G}_{\mathrm{rot}}\left(78{ }^{\circ} \mathrm{C}\right) & =115 \mathrm{~kJ} \cdot \mathrm{mol}-{ }^{-1} \\ \mathrm{t}_{1 / 2}\left(25^{\circ} \mathrm{C}\right) & =100 \text { days }\end{aligned}$

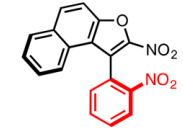

10 e, $81 \%, 89 \%$ ee, $93 \%$ cp $\Delta G_{\text {rot }}\left(78^{\circ} \mathrm{C}\right)=112 \mathrm{~kJ}$.mol

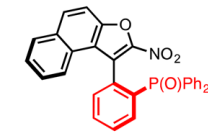

$10 \mathrm{~h}, 62 \%, 85 \% \mathrm{ee}, 89 \% \mathrm{cp}$ $\Delta G^{\ddagger}{ }_{\text {rot }}\left(182^{\circ} \mathrm{C}\right)=153 \mathrm{~kJ} \cdot \mathrm{mol}-1$ ${ }_{1 / 2}\left(25^{\circ} \mathrm{C}\right)=1$ million years

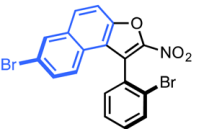
$10 \mathrm{k}, 77 \%, 92 \% \mathrm{ee}, 97 \% \mathrm{cp}$
$\Delta \mathrm{G}^{\mp} \mathrm{rot}^{\circ}\left(78^{\circ} \mathrm{C}\right)=123 \mathrm{~kJ} \cdot \mathrm{mol}^{-1}$
$\mathrm{t}_{1 / 2}\left(25^{\circ} \mathrm{C}\right)=6$ years

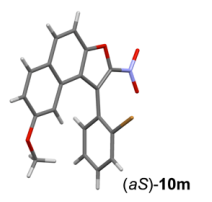

${ }^{a}$ Yields are for two steps.

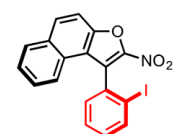

10c, $72 \%, 97 \%$ ee, $100 \%$ cp $\mathrm{t}_{1 / 2}\left(25^{\circ} \mathrm{C}\right)=230$ years

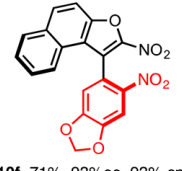

10f, $71 \%, 93 \%$ ee, $93 \%$ cp $\Delta \mathrm{G}_{\mathrm{rot}}^{\prime}\left(78^{\circ} \mathrm{C}\right)=115.6 \mathrm{~kJ} \cdot \mathrm{mol}^{-1}$ $\mathrm{t}_{1 / 2}\left(25^{\circ} \mathrm{C}\right)=130$ days

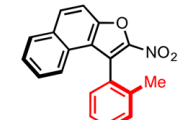

$10 \mathrm{i}, 74 \%, 92 \% \mathrm{ee}, 100 \% \mathrm{cp}$ $\Delta \mathrm{G}_{\mathrm{rol}}\left(78^{\circ} \mathrm{C}\right)=118 \mathrm{~kJ} . \mathrm{mol}$

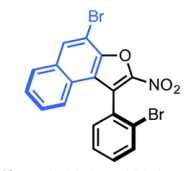

101, $75 \%, 98 \%$ ee, $100 \%$ cp $\mathrm{t}_{1 / 2}\left(25^{\circ} \mathrm{C}\right)=9$ years synthetically valuable halogens could be incorporated in the final furan structures with preserved high barriers to rotation and excellent $\mathrm{cp}$ as in the cases of chloro- and iodo-derivatives $10 b, c$, respectively. ${ }^{21}$ Other electron-withdrawing substituents such as an ester in 10d, a nitro in $10 \mathrm{e}-\mathrm{f}$, a trifluoromethyl $10 \mathrm{~g}$ or a phosphine oxide $10 \mathrm{~h}$ also behave with comparable efficiency and good to excellent cp from $89 \%$ to $100 \%$. Alternatively, a 2-tolyl substituent as in 10i is compatible with the sequence. Concerning the variation of the pronuceophile partner, we can notice that the overall process nicely tolerates the use of functionalized 2-naphthol derivatives bearing either methoxy or bromo substituents at various positions allowing the isolation of $\mathbf{1 0 j}-\mathbf{m}$ with very good yields, $>91 \%$ ee and $>96 \% \mathrm{cp}$. In this series also, X-ray diffraction analysis allowed to attribute the $(1 R, 2 S)$ and $(a S)$ absolute configurations to dihydrofuran $9 \mathrm{~m}$ and furan $10 \mathrm{~m},{ }^{19}$ respectively and to propose a mechanistic rationale (Scheme 7 ). In the case of dihydrofuran

Scheme 7. $\mathrm{MnO}_{2}$-Promoted Oxidation Mechanism

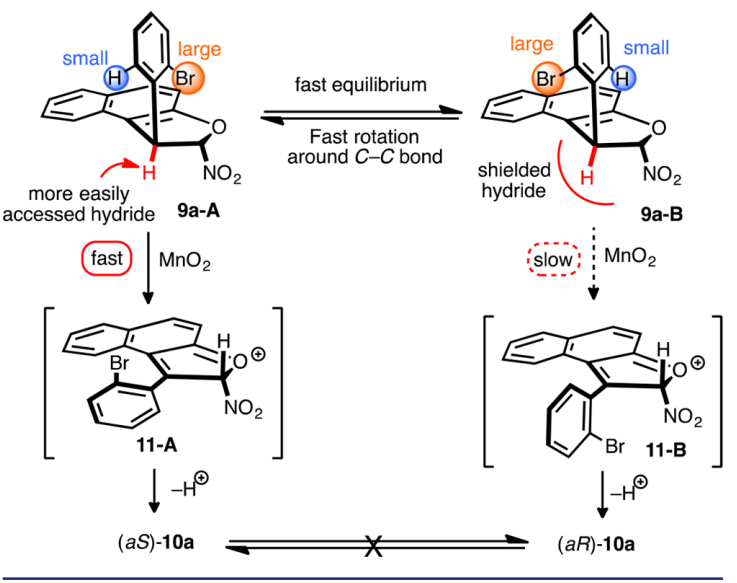

9a, because no atropodiastereomers can be visualized by ${ }^{1} \mathrm{H}$ NMR (see Supporting Information) we can argue for a fast equilibrium between the two rotamers $\mathbf{9 a - A}$ and $\mathbf{9 a - B}$. In the presence of manganese dioxide, hydride transfer could potentially afford two possible oxonium ion intermediates 11A and 11-B. We can reasonably expect that the hydride transfer would preferentially occur from conformation 9a-A in which the hydride is more easily accessed by the oxidant compared to the conformation 9a-B. Subsequent fast deprotonation of the acidic hydrogen atom in 11-A would then lead to the expected enantioenriched $(a S)$-10a with efficient central-to-axial chirality conversion.

In summary, we have developed an enantioselective synthesis of hitherto unknown furan atropisomers using a central-to-axial chirality conversion strategy based on the formation of the furan heterocycle, from acyclic precursors, and with the concomitant creation of the chiral axis. Two structurally different optically active heteroatropisomeric families displaying a five-membered heterocycle could be obtained with great efficiency from readily available substrates. The crucial central chirality in the dihydrofuran precursor is mastered by an enantioselective organocatalyzed $\mathrm{C}-\mathrm{O}$-heterocyclization sequence, and the chiral axis is revealed with good to excellent cp by an oxidative dehydrogenation with either $\mathrm{PhI}(\mathrm{OAc})_{2}$ or $\mathrm{MnO}_{2}$. 


\section{ACKNOWLEDGMENTS}

Financial support from the Agence Nationale pour la Recherche (ANR-13-BS07-0005), the Centre National de la Recherche Scientifique (CNRS), Aix-Marseille Université, is gratefully acknowledged. We also thank Daniel Dauzonne (Institut Curie) for the synthesis and generous gift of some initial chloronitroalkenes in multigram quantities, and also for the know-how in the preparation of these species. Dedicated to the friendship and memory of Prof. Teodor Silviu Balaban, former colleague of the authors.

\section{REFERENCES}

(1) (a) McCarthy, M.; Guiry, P. J. Tetrahedron 2001, 57, 3809. (b) Tang, W.; Zhang, X. Chem. Rev. 2003, 103, 3029. (c) Shimizu, H.; Nagasaki, I.; Saito, T. Tetrahedron 2005, 61, 5405.

(2) (a) Brandes, S.; Niess, B.; Bella, M.; Prieto, A.; Overgaard, J.; Jørgensen, K. A. Chem. - Eur. J. 2006, 12, 6039. (b) Kano, T.; Yamaguchi, Y.; Maruoka, K. Chem. - Eur. J. 2009, 15, 6678. (c) Schenker, S.; Zamfir, A.; Freund, M.; Tsogoeva, S. B. Eur. J. Org. Chem. 2011, 2209.

(3) Wezenberg, S. J.; Ferroni, F.; Pieraccini, S.; Schweizer, W. B.; Ferrarini, A.; Spada, G. P.; Diederich, F. RSC Adv. 2013, 3, 22845.

(4) (a) Clayden, J.; Moran, W. J.; Edwards, P. J.; LaPlante, S. R. Angew. Chem., Int. Ed. 2009, 48, 6398. (b) Zask, A.; Murphy, J.; Ellestad, G. A. Chirality 2013, 25, 265.

(5) (a) Bringmann, G.; Mortimer, A. J. P.; Keller, P. A.; Gresser, M. J.; Garner, J.; Breuning, M. Angew. Chem., Int. Ed. 2005, 44, 5384. (b) Baudoin, O. Eur. J. Org. Chem. 2005, 4223. (c) Wencel-Delord, J.; Panossian, A.; Leroux, F. R.; Colobert, F. Chem. Soc. Rev. 2015, 44, 3418. (d) Shirakawa, S.; Liu, S.; Kaneko, S. Chem. - Asian J. 2016, 11, 330. (e) Special issue, Colobert, F., Ed., Tetrahedron 2016, 72, 5157. (f) For a highlight, see: Quinonero, O.; Bressy, C.; Bugaut, X. Angew. Chem., Int. Ed. 2014, 53, 10861.

(6) Kumarasamy, E.; Raghunathan, R.; Sibi, M. P.; Sivaguru, J. Chem. Rev. 2015, 115, 11239.

(7) For recent examples of enantioselective synthesis of chiral biaryls, see: (a) De, C. K.; Pesciaioli, F.; List, B. Angew. Chem., Int. Ed. 2013, 52, 9293. (b) Li, G.-Q.; Gao, H.; Keene, C.; Devonas, M.; Ess, D. H.; Kürti, L. J. Am. Chem. Soc. 2013, 135, 7414. (c) Link, A.; Sparr, C. Angew. Chem., Int. Ed. 2014, 53, 5458. (d) Chen, Y.-H.; Cheng, D.-J.; Zhang, J.; Wang, Y.; Liu, X.-Y.; Tan, B. J. Am. Chem. Soc. 2015, 137, 15062. (e) Moliterno, M.; Cari, R.; Puglisi, A.; Antenucci, A.; Sperandio, C.; Moretti, E.; Di Sabato, A.; Salvio, R.; Bella, M. Angew. Chem., Int. Ed. 2016, 55, 6525. (f) Fäseke, V. C.; Sparr, C. Angew. Chem., Int. Ed. 2016, 55, 7261. (g) Yu, C.; Huang, H.; Li, X.; Zhang, Y.; Wang, W. J. Am. Chem. Soc. 2016, 138, 6956. (h) Mori, K.; Itakura, T.; Akiyama, T. Angew. Chem., Int. Ed. 2016, 55, 11642.

(8) (a) For a review on atropisomerism in heteroaromatic compounds, see: Alkorta, I.; Elguero, J.; Roussel, C.; Vanthuyne, N.; Piras, P. Adv. Heterocycl. Chem. 2012, 105, 1-188. (b) Djafri, A.; Roussel, C.; Sandström, J. J. Chem. Soc., Perkin Trans. 2 1985, 273277. (c) Lomas, J. S.; Lacroix, J.-C.; Vaissermann, J. J. Chem. Soc., Perkin Trans. 2 1999, 2001. (d) Benincori, T.; Brenna, E.; Sannicolo, F.; Trimarco, L.; Antognazza, P.; Cesarotti, E. J. Chem. Soc., Chem. Commun. 1995, 685.

(9) Yamaguchi, K.; Yamaguchi, J.; Studer, A.; Itami, K. Chem. Sci. 2012, 3, 2165.
(10) During the revision process of this paper, the group of Shi and $\mathrm{Li}$ published an article describing the enantioselective construction of axially chiral naphthyl-indole skeletons: Zhang, H.-H.; Wang, C.-S.; Li, C.; Mei, G.-J.; Li, Y.; Shi, F. Angew. Chem., Int. Ed. 2016, 55, DOI: 10.1002/anie.201608150

(11) In its strict definition, conversion of chirality is a chemical process consisting in the destruction of a stereogenic element on a molecule with the simultaneous installation of another stereogenic element of a different nature. For further details, see: Wolf, C. In Dynamic Stereochemistry of Chiral Compounds: Principles and Applications; RSC: Cambridge, 2007; pp 233-271.

(12) (a) For seminal studies, see: Berson, J. A.; Brown, E. J. Am. Chem. Soc. 1955, 77, 450. (b) Meyers, A. I.; Wettlaufer, D. G. J. Am. Chem. Soc. 1984, 106, 1135. For other examples of central-to-axial chirality conversion to access all-carbon biaryls, see: (c) Shindo, M.; Koga, K.; Tomioka, K. J. Am. Chem. Soc. 1992, 114, 8732. (d) Straub, A.; Goehrt, A. Angew. Chem., Int. Ed. Engl. 1996, 35, 2662. (e) Hattori, T.; Date, M.; Sakurai, K.; Morohashi, N.; Kosugi, H.; Miyano, S. Tetrahedron Lett. 2001, 42, 8035. (f) Nishii, Y.; Wakasugi, K.; Koga, K.; Tanabe, Y. J. Am. Chem. Soc. 2004, 126, 5358. (g) Wanjohi, J. M.; Yenesew, A.; Midiwo, J. O.; Heydenreich, M.; Peter, M. G.; Dreyer, M.; Reichert, M.; Bringmann, G. Tetrahedron 2005, 61, 2667. (h) Liu, Y.; Lu, K.; Dai, M.; Wang, K.; Wu, W.; Chen, J.; Quan, J.; Yang, Z. Org. Lett. 2007, 9, 805. (i) Shindo, M.; Yamamoto, Y.; Yamada, K.; Tomioka, K. Chem. Pharm. Bull. 2009, 57, 752. (j) Guo, F.; Konkol, L. C.; Thomson, R. J. J. Am. Chem. Soc. 2011, 133, 18. (k) Konkol, L. C.; Guo, F.; Sarjeant, A. A.; Thomson, R. J. Angew. Chem., Int. Ed. 2011, 50, 9931. (1) Prause, F.; Arensmeyer, B.; Frohlich, B.; Breuning, M. Catal. Sci. Technol. 2015, 5, 2215. (m) Wang, J.-Z.; Zhou, J.; Xu, C.; Sun, H.; Kürti, L.; Xu, Q.-L. J. Am. Chem. Soc. 2016, 138, 5202. (n) Feng, J.; Li, B.; He, Y.; Gu, Z. Angew. Chem., Int. Ed. 2016, 55, 2186.

(13) Quinonero, O.; Jean, M.; Vanthuyne, N.; Roussel, C.; Bonne, D.; Constantieux, T.; Bressy, C.; Bugaut, X.; Rodriguez, J. Angew. Chem., Int. Ed. 2016, 55, 1401

(14) (a) Rueping, M.; Parra, A.; Uria, U.; Besselièvre, F.; Merino, E. Org. Lett. 2010, 12, 5680. (b) Fan, L.-P.; Li, P.; Li, X.-S.; Xu, D.-C.; Ge, M.-M.; Zhu, W.-D.; Xie, J.-W. J. Org. Chem. 2010, 75, 8716. (c) Dou, X.; Zhong, F.; Lu, Y. Chem. - Eur. J. 2012, 18, 13945. (d) Becerra, D.; Raimondi, W.; Dauzonne, D.; Constantieux, T.; Bonne, D.; Rodriguez, J. Synthesis 2017, 49, 195. (e) For the synthesis of achiral furans from (Z)-(2-halo-2-nitroethenyl)benzenes, see: Raimondi, W.; Dauzonne, D.; Constantieux, T.; Bonne, D.; Rodriguez, J. Eur. J. Org. Chem. 2012, 6119 .

(15) (a) Jarava-Barrera, C.; Esteban, F.; Navarro-Ranninger, C.; Parra, A.; Alemán, J. Chem. Commun. 2013, 49, 2001. (b) Pan, J.-Y.; Li, X.-S.; Xu, D.-C.; Xie, J.-W. Aust. J. Chem. 2013, 66, 1415.

(16) (a) Dauzonne, D.; Royer, R. Synthesis 1988, 339. (b) Dauzonne, D.; Demerseman, P. J. Heterocycl. Chem. 1990, 27, 1581. (c) Dauzonne, D.; Josien, H.; Demerseman, P. Tetrahedron 1990, 46, 7359. (d) Dauzonne, D.; Grandjean, C. J. Heterocycl. Chem. 1994, 31, 1021

(17) (a) Malerich, J. P.; Hagihara, K.; Rawal, V. H. J. Am. Chem. Soc 2008, 130, 14416. (b) For a review, see: Chauhan, P.; Mahajan, S.; Kaya, U.; Hack, D.; Enders, D. Adv. Synth. Catal. 2015, 357, 253.

(18) Lu, S.-C.; Zheng, P.-R.; Liu, G. J. Org. Chem. 2012, 77, 7711.

(19) $(2 S, 3 S)-3 \mathrm{~d},(\mathrm{a} S)-\mathbf{4 d},(1 R, 2 S)-9 \mathrm{~m}$ and $(\mathrm{a} S)-10 \mathrm{~m}$ refer to CCDC 1505555, CCDC 1505557, CCDC 1505556, CCDC 1505558 respectively, which contain the supplementary crystallographic data for this paper. These data can be obtained free of charge from The Cambridge Crystallographic Data Centre via www.ccdc.cam.ac.uk.

(20) With other hindered aryl groups (e.g., 2-methylnaphthyl, 2bromo-6-methylphenyl, 2-methyl-6-nitrophenyl), the corresponding furans proved unstable during the oxidation step.

(21) With fluorine atom, the barrier to rotation was only of $85 \mathrm{~kJ}$ $\mathrm{mol}^{-1}$ preventing the isolation of a stable atropisomer of the corresponding furan. 